\title{
Population, distribution, and habitat of Bornean Elephant in Tulin Onsoi, Nunukan District, Indonesia based on dung counts
}

\author{
WISHNU SUKMANTORO ${ }^{1, \vartheta}$, AGUS SUYITNO ${ }^{2}$, MULYADI ${ }^{2}$, DONI GUNARYADI ${ }^{1}$, AGANTO SENO ${ }^{3}$, \\ ALFRED INDRA KUSUMA ${ }^{4}$, DARWIS \\ ${ }^{1}$ Indonesia Elephant Foundation (Perkumpulan Gajah Indonesia). Jl. Kreta Kencana A5 No. 32, Sektor 12-BSD, South Tangerang 15310, Banten, \\ Indonesia."email: wishnubio74@gmail.com \\ ${ }^{2}$ WWF Indonesia-Kayan Landscape Program. Jl. Mangga, Tanjung Selor, Bulungan 77212, North Kalimantan, Indonesia \\ ${ }^{3}$ BKSDA East Kalimantan. Jl. Teuku Umar No. 17, Karanganyar, Samarinda 75243, East Kalimantan, Indonesia \\ ${ }^{4}$ Perkumpulan Lintas Hijau. Jl. Jend. Sudirman, Selisun, Nunukan Selatan, Nunukan 77482, North Kalimantan, Indonesia
}

Manuscript received: 13 December 2019. Revision accepted: 23 December 2020

\begin{abstract}
Sukmantoro W, Suyitno A, Mulyadi, Gunaryadi D, Seno A, Kusuma AI, Darwis. 2021. Population, distribution, and habitat of Bornean Elephant in Tulin Onsoi, Nunukan District, Indonesia based on dung counts. Biodiversitas 22: 311-319. The survey on population, distribution, and habitat of Bornean elephants is very important because it reduces the information gap about Bornean elephants' population and distribution. In more detail, the study can be used for updating information and the needs of local government in a spatial plan based on biodiversity conservation. The survey of Bornean Elephant was conducted in Tulin Onsoi Subdistrict, Nunukan District, North Kalimantan Province, Indonesia, starting in February 2018 to May 2019. The survey area's scopes are Agison, Sibuda, Apaan, and Tampilon sub-water catchment areas in $34\left(5 \times 5 \mathrm{~km}^{2}\right)$ grids with a total of $850 \mathrm{~km}^{2}$. The occupancy method with perpendicular line transect was used in this study. In the survey, the number of traces was 52 finding points with a total of 241 traces. The elephant dung identified in the dung piles (one-time defecation) was in 29 finding points with a total of 38 dung piles ( 0.22 dung piles per $\mathrm{km}$ ). Based on Distance 6.0 and involved the formula of the elephant population's density with standard defecation and dung decay ratio, the elephant population density in the Tulin Onsoi is between 4.8-5.7 individuals $/ 100 \mathrm{~km}^{2}$. Minimum convex polygon (MCP)-qHull showed that the area of the elephant habitat is $253.12 \mathrm{~km}^{2}$ in Tulin Onsoi sub-district. Generally, the habitat conditions for the location are old secondary forests $(37 \%)$. Meanwhile, other habitats included in the survey area are primary forest, shrubs, and plantations, including community agriculture and roads. In the strategy of managing the Bornean elephant, efforts to stabilize or increase population are important things to do. Conservation-based spatial planning and close monitoring for the protection of small populations of this species and its threats, are options that can be selected for present and future in North Kalimantan.
\end{abstract}

Keywords: Bornean elephant, Tulin Onsoi, population, occupancy, dung counts

\section{INTRODUCTION}

The Bornean elephant (Elephas maximus borneensis) is one of the sub-species of Asian elephants living on the island of Borneo. The spread of these elephants in the northern region of Borneo, namely Sabah (eastern part of Malaysia) and North Kalimantan (part of Indonesia), is between 300-1500 m above sea level (asl) with mainly Dipterocarpaceae forests as their habitat. However, several other groups now occur in habitats that have been converted into plantations and settlements. The estimate of 500-2000 individuals was based on a survey conducted in Sabah (Tabin Wildlife Reserve, Lower Kinabatangan, and Deramakot Forest Reserve) by Andau et al. (1992), no survey was done in the Kalimantan area.

Bornean elephants are considered to have a smaller body morphology than other Asian elephants with a body size of 72-90\% of other Asian elephants (Cranbrook et al. 2008). This comparison of morphology is based on the calculation of measured female elephant skulls and other Asian elephants. The elephant's range is 4,000-12,000 ha (Alfred et al. 2007 Sitompul 2011). Taxonomic DNA study revealed that this elephant belongs to a separate sub-species because Bornean elephant separated from the other Asian elephant sub-species around 200,000 years ago (Fernando et al. 2003). The recent study by Sharma et al. (2018),' stated that the subspecies is endemic to Borneo where a bottleneck was identified likely between 11,000 and 18,000 years ago-at the end of the last glacial maximum when land bridges were still connected to Sundaland. However, some elephant experts also stated that some of the elephant population was the result of the introduction by the Sultan of Sulu (Davies and Payne 1982).

The main threat is land conversion increasing from year to year, especially land clearing in Sabah and North Kalimantan for settlements and plantations (Alfred et al. 2010). This resulted in retaliatory killing due to conflict between elephants and humans in several locations and hunting for ivory. Both are the primary cause of death of Bornean elephants in the field. Some events, Bornean elephants died en masse, for example, the case of the death of 14 individuals in 2013 or 25 individuals in 2018 by suspected poisoning, trapping and shooting in Sabah (Winarno 2013; Christiastuti 2018). Since 1986, Kalimantan elephant has been classified as endangered by the IUCN (Ambu et al. 2002; Choudhury et al. 2008). 
In North Kalimantan, conservation efforts are carried out by conducting studies on the elephants' presence, encouraging the mitigation of human-elephant conflict, and anti-poaching. In the evaluation and action plan of Bornean elephants, the study of the existence, population, and distribution of them are one of the important recommendations (Wulffraat 2006; Seno et al. 2018). Then, at the conservation network level, the elephant study, especially in the North Kalimantan Province of Indonesia, is the main priority, especially to get the latest population and distribution.

Occupancy study of elephants based on dung counts is the highest importance because it is a standard method for calculating the population and distribution of this species, is cheap and involves a lot of field personnel. The study was conducted by involving a field team; the East Kalimantan BKSDA (Nature Conservation Agency), North Kalimantan BPLH (Environmental Management Bureau), WWF Indonesia, PGI (Indonesian elephant association), and PLH (Environmental Association Society) of North Kalimantan. This study was also assisted by local people in the Tulin Onsoi area.

\section{MATERIALS AND METHODS}

\section{Sampling sites, population and distribution of the elephant}

The study was conducted in Tulin Onsoi Subdistrict, Nunukan District, North Kalimantan Province, Indonesia starting in February 2018-May 2019. The scope of the study area is in four areas, namely Agison, Sibuda, Apaan, and Tampilon. A study with a duration of almost 1.5 years (7 surveys) began with a series of training activities and simulations of the application of elephant occupancy methods in Tarakan and Malinau, North Kalimantan. The training focused on preparing and applying datasheet forms for elephant surveys and their habitat and datasheet form usage simulations in the field.

The occupancy method with perpendicular line transect was used in this study. The grid used some samplings of 5 x $5 \mathrm{~km}^{2}$ with a perpendicular line transect of $5-7 \mathrm{~km}$ or 5 grids $1 \times 1 \mathrm{~km}^{2}$, which have been prepared and become part of the $5 \times 5 \mathrm{~km}^{2}$ grid. The $1 \mathrm{~km}$ (a part of total $5-7 \mathrm{~km}$ perpendicular line transect) is divided into 10 observation segments with each segment within $100 \mathrm{~m}$ starting from segments 1 to 10 . Determination of sampling grids was based on previous survey records of the elephant intensity of use in 2007-2011 covered the Agison, Tapilon, Apaan, and Sibuda regions (Mongabay 2012). The total grid sampling of $5 \times 5 \mathrm{~km}^{2}$ is 34 grids, or the total scope of the study area is $850 \mathrm{~km}^{2}$. The total grid of $1 \mathrm{x} 1 \mathrm{~km}^{2}$ used in this study is 170 grids.
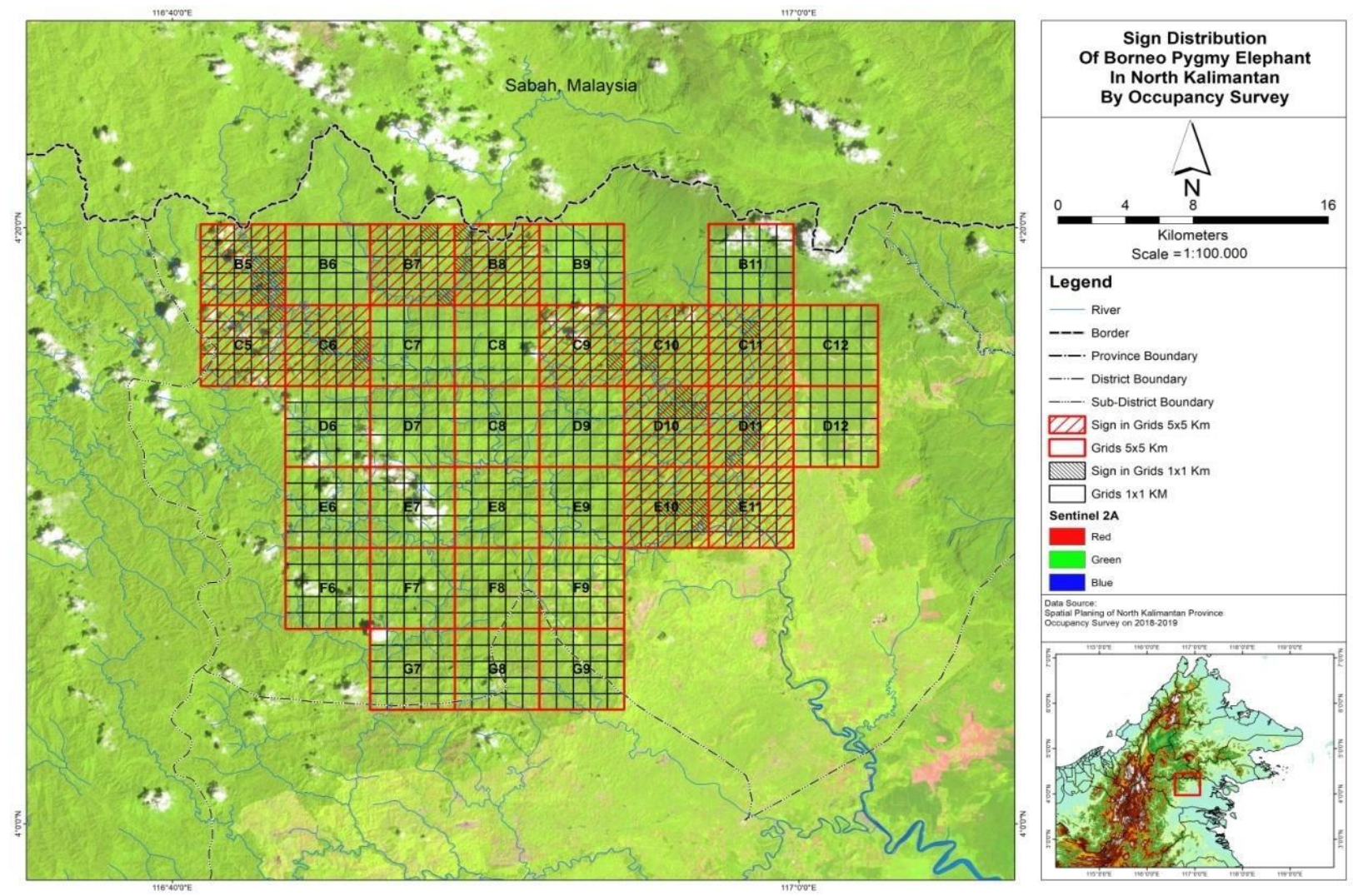

Figure 1. The Bornean elephant occupancy survey in $5 \times 5 \mathrm{~km}^{2}$ and 1 x $1 \mathrm{~km} 2$ grids at Tulin Onsoi, Nunukan District, North Kalimantan, Indonesia (Source of map: Sentinel 2 Imagery 2018 \& 2019) 
The survey team was divided into four teams where one team numbered between $10-12$ people, $3-4$ core teams, and porters (including sampan owners) from the local Dayak community. The overall survey was carried out by river transportation then continued on walking for perpendicular line transects. Occupancy studies are carried out by determining the starting point of the survey then the team travels $5 \mathrm{~km}$ on perpendicular transects. The survey team run according to the established transect route and the route could be modified to adjust the contour of the land if it was difficult to pass or reach. The survey team in collecting field data needed a datasheet form book, and each team member filled out the sheet form data in detail following the guiding standard.

The study sheet was carried out by adopting a Sumatran elephant occupancy study in Riau and then modified it according to the study needs in Kalimantan. The datasheet was divided into five types, i.e., A, B, C, D, and E, Type A (A1-A8) are general information of the study, survey team information, and time and coordinates starting and completing the study. Sheet B is a general type of habitat or ecosystem in the survey area, its management system and its main threat. Type $\mathrm{C}(\mathrm{C} 1-\mathrm{C} 33)$ is a description of a $5 \times 5$ $\mathrm{km}^{2}$ grid and a $1 \times 1 \mathrm{~km}^{2}$ grid and ecosystem conditions and threats per segment (1-10 segments) in a $1 \mathrm{~km}$ perpendicular line transect. Type D data sheet is a more detailed explanation of the signs of the presence of Bornean elephants per segment. The type E data sheet is a description of the position of coordinates from the results of these observations.

Data analysis was carried out in two stages. The first was by using the standard formula of elephant dung and DISTANCE 6.0 to estimate the pattern of fecal distribution and standard error. ARCGIS 10.5 to determine the distribution of elephants based on feces, traces or other signs, using MCP (Minimum Convex Polygon). The second was by using qHull and Kernel Density 10-30\%, $30-50 \%$ and $50-100 \%$ to determine the concentration chamber findings to estimate the Bornean elephant range.

In the dung count survey (recce survey), the stratification of dung piles was identified in low status ie 020 dung piles per $\mathrm{km}$ and high stratification ie 20.1-45 dung piles per km (Reilly 2002; Hedges et al. 2005). The defecation rate for Sumatran elephants in Way Kambas is 16.68 (Sukmantoro 2002) or 18.15 (Tyson et al. 2002) and specifically of Bornean elephant in Sabah is 8.68 (SD = 1.67) (Alfred et al. 2010). The dung decay rate calculation is $133,29(0,0075$ per day $)$ based on a Bornean elephant study in Sabah, Malaysia (Alfred et al. 2010). The formula used is;

$\mathrm{E}=\mathrm{Y} \times \mathrm{r} / \mathrm{D}$

Where:

$\mathrm{E}=$ Population density per unit area

$\mathrm{Y}=$ amount of dung piles in units of area

$\mathrm{r}=$ dung decay rate $(0.0075)$

$\mathrm{D}=$ defecation ratio (8.68 (Alfred et al. 2010)
$\mathrm{Y}$ is $\mathrm{n} / \mathrm{f}(\mathrm{x}) * 2 \mathrm{~L}$

Where:

$\mathrm{Y}=$ amount of dung piles in units of area

$\mathrm{f}(\mathrm{x})$ or $\mathrm{D}=$ function of distance or distance of dung piles with perpendicular transects

$\mathrm{L}=$ length of transect

\section{Habitat condition}

Datasheet form contained information on the Bornean elephant habitat conditions per grid and segment. Information on site conditions can describe land cover, land status or area, watershed or water source, and mineral lick and the threats to the habitat and population of Kalimantan elephants. Analysis of habitat data is done by calculating the relative percentage of each land cover type, watershed or water source and mineral salting, and threat type.

\section{RESULTS AND DISCUSSION}

\section{Samples distribution in the research area}

Distribution of trace, feces, friction, and estimated elephant puddles are found in the survey location (Figure 1). Based on the perpendicular distance from the findings of signs of the presence of these elephants (sampling) with perpendicular transects, the distance of $0-1 \mathrm{~m}$ from the transect has the highest sampling findings $(62 \%)$. Between 1-2 $\mathrm{m}$ and 2-3 $\mathrm{m}$ distances, a sampling of $11(11 \%)$ and 15 $(15 \%)$ records of the presence of elephants were also recorded.

A total of 13 dung samples were recorded at a distance of $0-1 \mathrm{~m}(45 \%)$ when concentrated on the findings of elephant dung. Then in 1-2 $\mathrm{m}$ was recorded five dung samples (17\%), 2-3 m collected nine dung samples (31\%). At 3-4 $\mathrm{m}$ distance, there did not found the elephant dung during the survey. In the context of population studies, a distance of $0-3 \mathrm{~m}$ is ideal in obtaining elephant dungs in the field based on the number of records of findings of sampling. In the previous document, the effective distance of monitoring elephants from perpendicular transects was 6 m (Sukmantoro et al. 2018).

\section{Current population estimates of all survey activities}

From a total of seven occupancy surveys in 34 grids ( 5 x $5 \mathrm{~km}^{2}$ grid cell) and 170 grids $\left(1 \times 1 \mathrm{~km}^{2}\right.$ grid cell) or 170 $\mathrm{km}$ of perpendicular line transect totally, the number of traces was 52 finding points with a total 241 traces (Table 1 ). The elephant dung identified in the dung piles (1-time defecation) was in 29 finding points with a total of 38 dung piles $(0,22$ dung piles per $\mathrm{km})$. The survey team also identified elephant body friction in plants at 17 friction points in height between 2 and $3.5 \mathrm{~m}$. For animal pools, the team also identified three locations and was thought to be a place for elephant activities. 

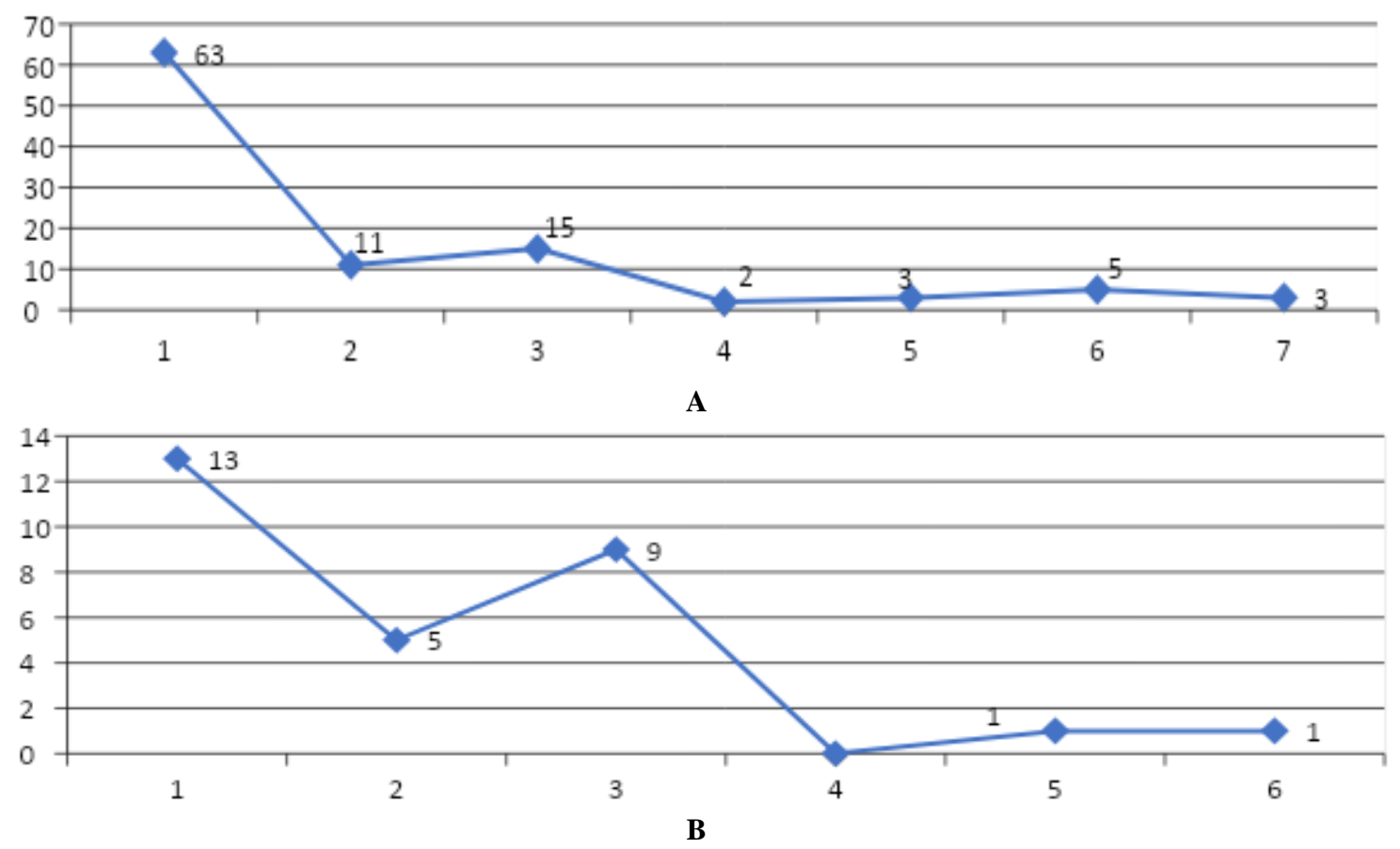

Figure 2. A. Graph of sampling distribution in the distance from perpendicular transects for all signs of the presence of elephants. B. For other images is the distribution of dung sampling within the distance of the perpendicular transect

Signs of the presence of elephants (traces, dung, body friction, and other signs) were identified in $10\left(5 \times 5 \mathrm{~km}^{2}\right)$ grids namely C11, D11, B5, C6, C10, D10, B7, E10, B8 and C9. For specific elephant dung concentrated in 8 (5 x 5 $\mathrm{km}^{2}$ ) grids, namely D11, B5, C5, C6, C10, D10, E10 and B8. DISTANCE 6.0 is used to obtain elephant discharge density which results in a distance function value $(\mathrm{F}(\mathrm{x}))$ or $\mathrm{D}$ is $61.001(\mathrm{AIC}=214.59, \mathrm{ESW}=1.06, \mathrm{D} \mathrm{LCL}=55.95$, D UCL $=66.51(95 \%$ CI $), \mathrm{D} \mathrm{CV}=0.044)($ Table 2$)$.

In calculating species populations directly, the DISTANCE 6.0 program can be used to calculate the population density of species. Still, for indirect methods such as dung, this program only calculates dung density, and then is done by calculating elephant population density with standard elephant dung formula. If an elephant population is calculated where the defecation ratio is 8,68 (Alfred et al. 2010) and the dung decay ratio is 0.0075 . The elephant population density in Tulin Onsoi is between $0,053 / \mathrm{km}^{2}$ (range $0.048-0,057 / \mathrm{km}^{2}$. When extrapolated in an area of $100 \mathrm{~km}^{2}$, the population estimation is 5.3 individuals in $100 \mathrm{~km}^{2}$ (or 4.8-5.7 individuals $/ 100 \mathrm{~km}^{2}$ ).

From the field notes with differences in circumference and diameter of elephant dung manually, it is estimated that there are seven individual elephants in all survey areas; one individual in the B5 grid (transect 1), three individuals in E10, C11, and D11 (transects 14 and 15) because of differences boli, and three individuals on-grid B7 and B8. On-grid D11-segment 3, two dung piles were identified with a circumference measuring $50 \mathrm{~cm}$ and a diameter of $14 \mathrm{~cm}$. Then at E10 (transect 14; segments 3), there were recorded 1 discharge with $62 \mathrm{~cm}$ dung circumference and $20 \mathrm{~cm}$ dung diameter and E10 grid (15 segments, 10 transects) were also recorded one discharge with $44 \mathrm{~cm}$ dung circumference and $15 \mathrm{~cm}$ its diameter.

Minimum convex polygon (MCP)-qHull showed that the area of the elephant habitat is $253.12 \mathrm{~km}^{2}(25,311.84$ ha) in the Tulin Onsoi sub-district and borders the Sabah region, Malaysia (see Figure 3). Kernel density of 50$100 \%, 30-50 \%$, and $10-30 \% \%$ showed that the highest concentration area of Kalimantan elephant was $63.62 \mathrm{~km}^{2}$ (red polygon in Figure 3 (b)), then the second and third highest concentration was $32.55 \mathrm{~km}^{2}$ and $45.07 \mathrm{~km}^{2}$ (yellow and green polygons).

Bornean elephants in North Kalimantan are a subpopulation that can be considered separate from the Sabah population of elephants, especially from the small population in Tinampak, although it may also be related to the elephant population in Tampilon. In Agison, Sibuda, and Tampilon, elephant populations tend to interact or populations that also have access to the Sabah (Malaysia) region. Richard (2018) stated that Bornean elephants in Kalimantan also have a population in the northern Kalimantan territory of Indonesia and the importance of establishing a connection among transboundary or crosscountry management between Malaysia and Indonesia for the protection of Kalimantan elephants. Wulffraat et al. (2017) also stated that the importance of cross-country management for Kalimantan elephants in the context of the Heart of Borneo $(\mathrm{HoB})$ transboundary corridor area. 
Table 1. Signs of the presence of elephants at the occupancy survey location, Tulin Onsoi, North Kalimantan, Indonesia

\begin{tabular}{lccccl}
\hline \multicolumn{1}{c}{ Finding types } & $\begin{array}{c}\text { Total of finding } \\
\text { points }\end{array}$ & \% proportion & Total number & $\begin{array}{c}\text { \% } \\
\text { proportion }\end{array}$ & Finding types \\
\hline Elephant tracepoint & 52 & 50.98 & 241 & 83.68 & Traces \\
Elephant dung & 29 & 28.43 & 38 & 10.07 & Dung piles \\
Bodies friction & 17 & 16.67 & 17 & 5.56 & Friction \\
Water pool & 4 & 3.92 & 4 & 0.69 & Water pool \\
& 102 & 100.00 & 300 & 100.00 & \\
\hline
\end{tabular}

Table 2. Findings of the presence of elephants at the occupancy survey location, Tulin Onsoi, North Kalimantan, Indonesia

\begin{tabular}{ccccccccc}
\hline & D (RATE) & DD $($ RATE $)$ & AIC & ESW & D & DLCL & DUCL & D CV \\
\hline $\mathrm{D}$ & 8.68 & 0.0075 & 214.59 & 1.06 & 61.001 & 55.946 & 66.512 & 0.044 \\
\hline
\end{tabular}

Note: D (rate): defecation rate, DD (rate): dung decay rate, EWR: Effective Strip Width for line transect data, D: Density of dung per $\mathrm{km}^{2}$ ), CV $=$ Coefficient of variant, AIC: Akaike information criterion, DLCL: lower confidence limit of density, DUCL: upper confidence limit of density

Estimates of the Bornean elephant population in the North Kalimantan region are estimated to be less than 20 individuals or 0.1 individuals $/ \mathrm{km}^{2}$ (Alfred et al. 2011). Our result study is not much different than the estimated population by Alfred et al. (2011). If extrapolated in the elephant range in Tulin Onsoi, which is $253.12 \mathrm{~km}^{2}$, the estimated potential of the elephant population in their range is 13.4 individuals. Nevertheless, the pattern of distribution of the elephants seems aggregated (clustered distribution) due to geographical isolation or the condition of some habitats that are difficult to reach by them (in particular due to contours).

By a real or manual calculation in the field (direct observation), seven elephants in the field were inadequate in the group population size. These are divided into two small and separate groups in two limited distribution areas. The first group consisted of four individuals in Agison and Sibuda (B5, B7, and B8), and the second group consisted of three individuals in Tampilon, Apaan, and Tinampak (E10, C11, and D11). One individual elephant in Agison and Sibuda may be solitary or not integrated with three other individuals. From the group context, this is very small and minimal group size for Asian elephants compared to the other groups in Sri Lanka or in India (Sukumar 2003). It is possible that a strong bond group is the parent female elephant with a child or two adult females and one child.

In the context of elephant movements, elephants likely avoid steep or steep areas, are more likely to use the river as a place for them to move. In 2017 study on the behavior and ecology of elephants in Sabah, there were differences in the movement of elephants during the flooding season and non-flooding season, when the season was not flooded, elephants tended to move near the river or a radius of less than $1 \mathrm{~km}$ from the river (Othman 2017).
Even so, elephants also move a lot in easily accessible locations such as roads. In the period of flooding, elephants move away from the river and search for elevated locations with limited area, although many use natural forests (Alfred 2012; Othman 2017). These two separate small population groups may be able to relate through river border access when not flooded or connections with males who can access these two groups.

\section{Bornean elephant habitat}

Of the total $34\left(5 \times 5 \mathrm{~km}^{2}\right)$ grids surveyed or in repeat surveys, the habitat conditions for the location are generally old secondary forests (37\%). Primary forests were also relatively common in the target survey locations (9\%). Meanwhile, other habitats included in the survey area are shrubs and plantations, including community agriculture and roads. Some locations consist of two or three types of land cover, for example, primary and secondary forests recorded in several survey grids.

Primary forests are more dominant $(50 \%)$ with small disturbances in the Agison River region because the contours are difficult for humans to access. Then the Apaan River is also part of the primary forest $(33 \%)$. There are many secondary forests in the Tampilon River, Sibuda River, and parts of Apaan and Kabatang (50\% and up). Some locations with more than one or two types of land cover are the Tinampak village area, which consists of primary $(21 \%)$ and secondary forests, mixed bushes, and mixed community plantations (78\%). Then the Melalat River also consists of secondary forests, shrubs, and community plantations. Tau Baru Village also consists of two or three habitat types for elephants, namely secondary forest, and mixed community plantations or monoculture oil palms or forestry cultivation areas. 

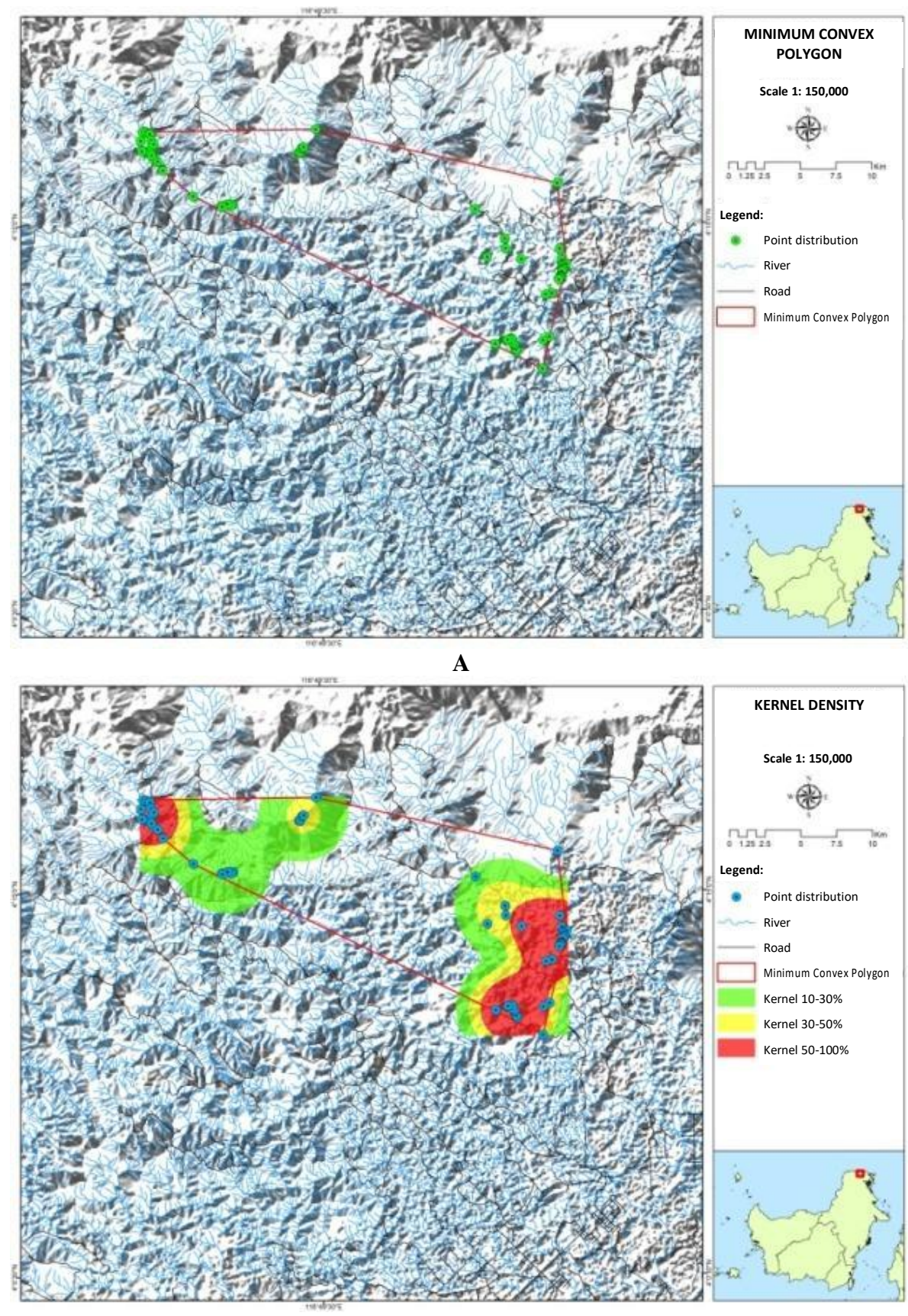

B

Figure 3. Elephant signing points (A) and MCP-qHull of Kalimantan elephants based on trace, feces, friction, and other signs (B) during the 2018-2019 survey activities

From this survey, the elephant's dominant habitat from the total data collection in the transect segment among 1838 segments was a secondary forest with canopy cover $41-60 \%$ and $61-80 \%(52.9 \%)$ for trees above $30 \mathrm{~cm}$ in diameter. Whereas below $30 \mathrm{~cm}$ diameter, poles with canopy cover between $41-60 \%$ and $61-80 \%$ also more dominant (54\%) than more open canopy cover. Then in the area of elephant habitat, bush conditions varied with dominant cover reaching $61-80 \%(27.9 \%)$ and $41-60 \%$ $(26.1 \%)$. Some habitats were mixed forests, namely primary and secondary forests and young secondary forests. Some locations also showed dominated shrubs $(2.99 \%)$ and mixed forests $(3.8 \%)$. Besides, there are also plantations and community farming.

Agison, Tampilon, Apaan, and Sibuda are major rivers which are large rivers and small rivers with a percentage between 32 and $34 \%$ of the total identified locations, and in these areas. There are also rivers or marshy saplings (16\%), namely in Agison River, Jeruk Camp, Tulin Onsoi River, and Melalat. Sibuda River (3\%) was identified as a source of water and as a source of mineral salt for animals. 


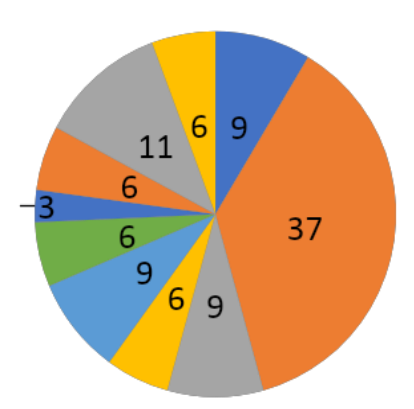

$\mathbf{A}$

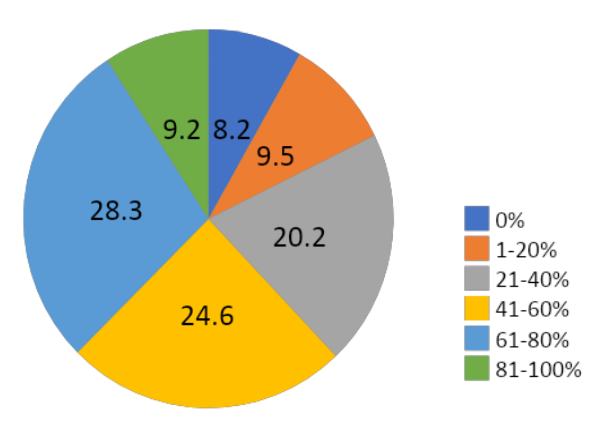

C

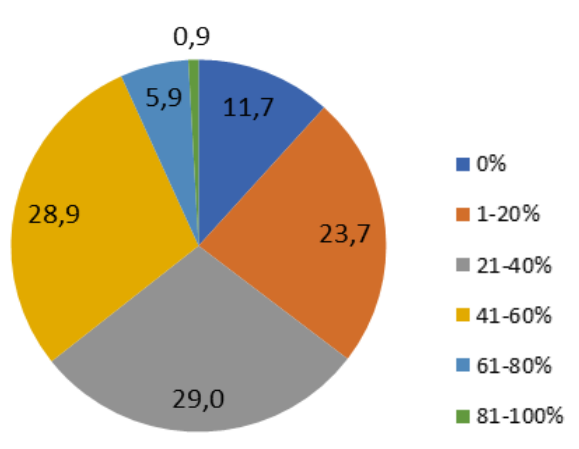

E
Primary forest

Secondary forest

Primary - secondary forest

Primary, secondary, bush \&

plantation

Primary, secondary \& plantation

Primary, secondary \& bush

Secondary forest, bush and

plantation

Secondary forest \& bush

Secondary forest \& plantation

Secondary forest and road

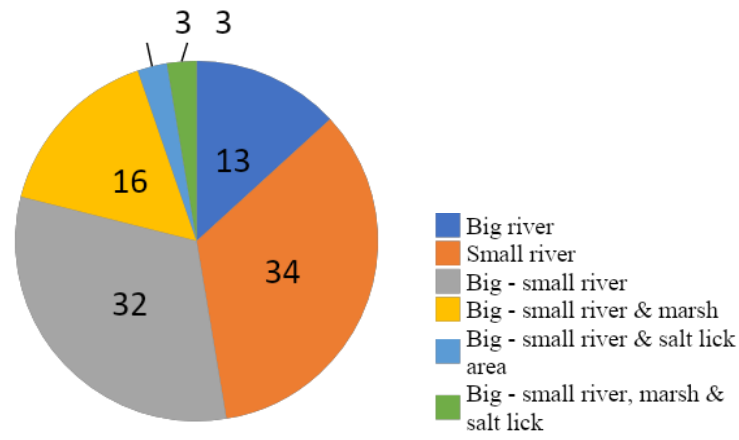

B

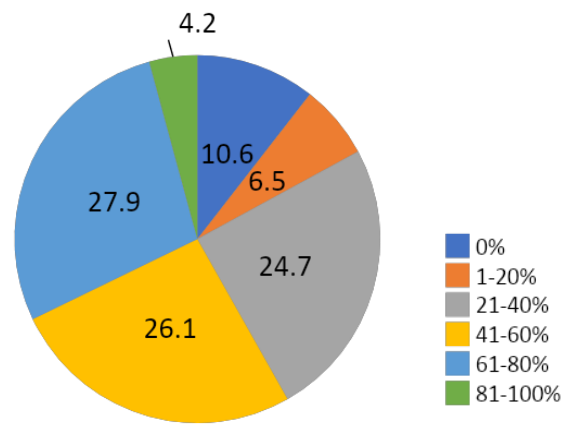

D

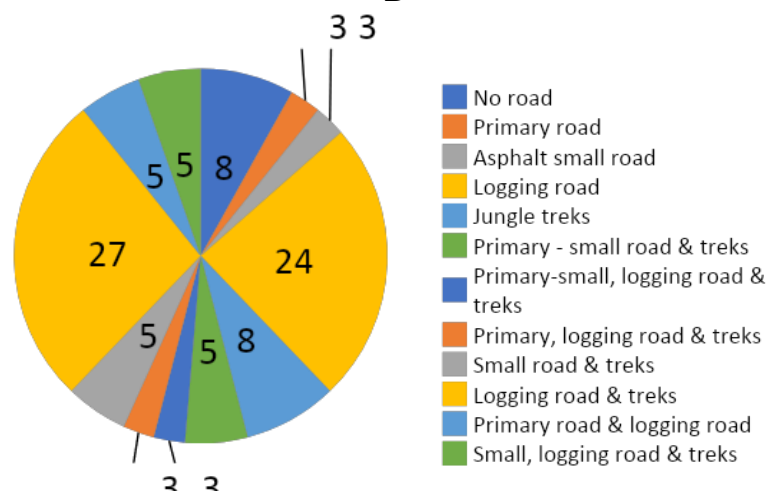

F

Figure 4. Bornean elephant habitat based on the forest cover (A), river types and salt lick areas (B) and detail of trees canopy >30 (C) diameter $<30 \mathrm{~cm}(\mathrm{D})$ diameter and shrub cover $(\mathrm{E})$, and road types inside the survey areas $(\mathrm{F})$

This is in accordance with habitat cover conditions using the spectral technique of Landsat OLI 8+ images in the area of elephant habitat in Tulin Onsoi, showing that the natural forest with a secondary forest type is dominantly followed by mixed gardens and fields and shrubs (Sukmantoro et al.2018). In Kinabatangan, Sabah, many elephants use swamp areas along the Kinabatangan river, in some natural forests and oil palm plantations, overlapping with community settlements and mixedplantations (Estes et al. 2012; Othman 2017). 66\% of this area is often flooded, narrowing the elephant's movement. Other studies suggest that Bornean elephant movements tend to be in degraded and forested areas $27 \%$ of them occurring within lands converted for agriculture: $24.2 \%$ in oil palm plantations, $0.7 \%$ in timber plantations, $0.58 \%$ in oil palm mix, and another $0.05 \%$ in rubber plantations (Evans et al. 2020).

In comparison with Sumatran elephants, habitat use for Kalimantan elephants is almost the same as the Sumatran elephant, which uses a lot of natural forests, especially habitat that has not been converted by humans. In SeblatBengkulu, Sumatran elephants use $45.5 \%$ of natural forest with a dense canopy, while those with open and non-dense canopies are between 22.6-28.3\%. Open areas are only $1.7 \%$ (Sitompul et al. 2013). In areas that have been heavily converted by humans, elephant habitat is mostly found in community plantations $(29.4 \%)$, then natural forests (21.4\%), and bush areas (9.8\%) (Sukmantoro et al. 2019). The habitat characteristics of the Bornean elephant in the study area are many hills and slopes so that the tendency for the elephants to use river borders is different 
from the population in Kinabatangan which tends to be flat (lowland). This condition is like in Aceh (Sumatra Island) where the elephants avoid the slope and are close to relatively flat river boundaries (Collins 2018). The characteristics of Bornean elephant habitat are supported by the condition of the foods identified as typical natural forest plants; ginger (Zingiberaceae), rattan (Calamoideae), wild palms (Arecaceae), fiber and ficus (Ficus sp.), and grasses (Poaceae) (Mingueza 2018). Some of them also like the type of lianas and bananas (Musa sp.).

\section{Threats}

The biggest threat to Borneo elephants in Kalimantan is hunting, especially using homemade firearms, animal snares, and poisoning. However, in the last year, there was no elephant death record in the North Kalimantan region. Conflict records of elephants-humans occurred in the last year (state the year), namely in the villages of Salang and Tinampak (Sub-district of Tulin Onsoi), where one elephant damaged community oil palm plantations. Poaching for ivory records has only been recorded in the Sabah region, where there were five cases of ivory circulation, which were later confiscated by East Kalimantan BKSDA officers. The most recent deaths of Bornean elephants recorded in various media channels are 14 individual elephants who died due to suspected poisoning in the Gunung Rara forest reserve, Tawau district-Sabah in 2013. Most likely due to the conflict with oil palm planters there.

Land conversion is the main threat in Tulin Onsoi Subdistrict, particularly for the Bornean elephant habitat in the present and future if it is not anticipated. Forest land conversion is a direct threat to this subpopulation. The direct threat is land seizure between the community and elephants, causing conflict, easier access for poachers, forest and land fires, and river pollution. All of these cause the quality decreased of the water sources' quality decreased for elephants and dietary requirements such as food, minerals, and shelter.

In calculating the quality of hunting threats, 238 segments from a total of 1838 segments (12.9\%) were indicated as high locations and very high hunting. While 933 other segments $(50.8 \%)$ indicated low to medium level for the threat of hunting. The threat of encroachment is 172 segments $(9.4 \%)$ that have high indications of very high threats. Meanwhile, 417 segments (23\%) indicated low to medium level. For the category of logging, 673 segments $(37 \%)$ indicated illegal logging with low to very high levels.

\section{Concluding remark}

During the survey period of 2018-2019, the data collection for the population and distribution of Bornean elephants in Tulin Onsoi was conducted using traces, feces, and other signs. Generally, trace findings and feces are more than 1 month or findings with a long age and relatively small amounts. Signs of the existence of the elephants were concentrated in two separate locations, namely in Agison-Sibuda where this location is in an elephant range, and one elephant group in Tampilon-
Apaan-Tinampak. In the context of population size, these two small groups occur in very minimal conditions. Although, both of them are likely to interact with other elephant groups that cross in the Sabah area and visit North Kalimantan. In a minimal group context, this group consists of close kinship; the parent and child or parent, other adult female elephants, and children. The pattern of care if it only consists of one parent and the other children will be disrupted because this minimal group does not have aunts as a childcare strategy after passing care from their parents. This separate group is also prone to local extinction and inbreeding, if there is no communication and interaction with adult males or female groups from larger populations. However, suppose the population structure estimation involves two individual children, especially in Agison and Sibuda. In that case, males exist in that location and these males are expected to be connected with other groups in Tulin Onsoi.

One of the strategies for managing the elephant population in Tulin Onsoi, is to step up on efforts to increase their population. One of the Emergency Action Plan efforts for the Bornean elephant population is to eliminate the potential threat because the threat of poaching will likely cause the local extinction of this subpopulation in this region in one or two cases; hunting and humanelephant conflict. Efforts to eliminate potential threats are by monitoring the elephants strictly and ensuring that they are safe from threats from hunting, namely by patrolling, monitoring and eliminating hunting of animals in the elephant habitat, confiscating and destroying animal snares and reducing coinage to land conversion to reduce elephant-human conflicts.

The effort to ensure that threats to elephants are addressed is an important and early effort in emergency action for the recovery of its population. Then, monitoring the movements of male elephants and restoring their habitat in target locations, especially river banks, is crucial to facilitate the transboundary movement of male elephants or elephant groups between Sabah and Kalimantan to increase their accessibility to larger foraging grounds and to ensure a healthy viable gene pool. Another intervention is the introduction/translocation of other Bornean elephants to this location is also very important to encourage an increase in elephant population in this location. The strategy and action plan of the Bornean elephant that was built and approved by the Governor this year was another effort to encourage spatial planning policies that factor in elephant requirement and to build better and more definite elephant corridor governance including cooperation between Malaysia and Indonesia for the management of them in the Nunukan region as Heart of Borneo transboundary corridor initiatives to ensure long term survival of Bornean elephant subpopulation in Kalimantan. The spatial policy prepared for the government of North Kalimantan Province is the establishment of an Essential Ecosystem Area especially for the elephant corridor contained in Government Regulation No. 28 of 2011. Tightening and licensing moratorium in Bornean elephant habitat is essential contributing to the planned recovery of this species. 
The use of GPS Collars is an important tool to monitor the movement of the elephants in Nunukan in more detail, but the problem is that during the survey, directly finding of elephant were never held, so the installation effort was temporarily undermined. Nevertheless, after this survey or research, monitoring of Bornean elephants can be done by installing camera traps in target locations and adjusting to the time of elephant visits to that location. In addition, the creation of field research camps and team efforts to move more quickly in a flying camp, encouraged the effectiveness of the Kalimantan elephant data collection at Tulin Onsoi.

\section{ACKNOWLEDGEMENTS}

We thank the Indonesian government (Ministry of Environmental and Forestry) to give support and permit us to carry out this study. We also thanks WWF Indonesia and TFCA (Tropical Forest Conservation Act) Kalimantan for supporting the fund us and also thanks to all of the field team and the local communities who helped us during the survey at our target locations with high dedication so that this survey worked well. Finally, we also thank Cheryl Cheah for helping to improve this paper and all staff of East Kalimantan BKSDA, members of the Indonesian Elephant Conservation Forum and Perkumpulan Lintas Hijau for supporting this activity.

\section{REFERENCES}

Andau M, Dawson S, Sale J. 1992. A review of elephant numbers in Sabah. Gajah 18: 41-45.

Alfred R, Williams CA, Verteteulle, Payne J, Andau P, Ambu L, Sipangkui S, Lim A. 2007 Satellite Tracking of Borneo's Pygmy Elephants. AREAS-WWF Malaysia.

Alfred R, Ahmad AH, Payne J, William C, Ambu L. 2010. Density and population estimation of the Bornean elephants (Elephas maximus borneensis) in Sabah. J Biol Sci 10 (2): 92-102.

Alfred R, Ambu L, Senthivel KS, Nathan S, Goosens B. 2011. Current status of Asian Elephants in Borneo. Gajah 35: 29-35.

Alfred R, Ahmad AH, Payne J, William C, Ambu LN, How PM, Goosens B. 2012. Home range and ranging behavior of Borneo elephant (Elephas maximus borneensis) females. PLoS One 7 (2): e31400. DOI: 10.1371/journal.pone.0031400.

Ambu LN, Andua PM, Nathan S, Tuuga A, Jensen SMC, Alfred R, Payne J. 2002. Asian Elephant Action Plan Sabah (Malaysia). Sabah Wildlife Department, Kota Kinabalu.

Choudhury A, Lahiri Choudhury DK, Desai A, Duckworth JW, Easa PS, Johnsingh AJT, Fernando P, Hedges S, Gunawardena M, Kurt F, Karanth U, Lister A, Menon V, Riddle H, Rübel A, Wikramanayake E. (IUCN SSC Asian Elephant Specialist Group). 2008. Elephas maximus. The IUCN Red List of Threatened Species 2008: e.T7140A12828813.

Christiastuti N. 2018. Malaysia selidiki kematian puluhan gajah kerdil langka di Sabah. News.detik.com/international. [Indonesian]

Collins NJ. 2018. Sumatran elephant Elephas maximus sumatranus density and habitat use in relation to forest characteristics in the Leuser Ecosystem, North Sumatra. [Thesis]. Bournemouth University, UK.

Cranbrook E, Payne J, Leh CMU. 2008. Origin of the elephants Elephas maximus L. of Borneo. Sarawak Mus J 63: 95-125.
Davies G, Payne J. 1982. A Faunal Survey of Sabah. WWF Malaysia for the Game Branch, Forestry Department of Sabah, Kota Kinabalu.

Estes JG, Othman N, Ismail S, Ancrenaz M, Goossns B, Ambu LN, Estes AB, Palmiotto PA. 2012. Quantity and configuration of available elephant habitat and related conservation concerns in the lower Kinabatangan floodplain of Sabah, Malaysia. Plos One 7 (10): e44601. DOI: 10.1371/journal.pone.0044601.

Evans LJ, Goossens B, Davies AB, Reynolds G, Asner GP. 2020. Natural and anthropogenic drivers of Bornean elephant movement strategies. Global Ecol Conserv 22: 1. DOI: 10.1016/j.gecco.2020.e00906.

Fernando P.Vidya TNC, Payne J, Stuewe M, Davison G, Alfred RJ, Andau, PBosi, Kilbourn E, A. Melnick DJ. 2003. DNA analysis indicates that Asian elephants are native to Borneo and are therefore a high priority for conservation. Plos Biol 1 (1): e6. DOI: 10.1371/journal.pbio.0000006.

Hedges S, Tyson MJ, Sitompul AF, Kinnaird MF, Gunaryadi D, Aslan. 2005. Distribution, status, and conservation needs of Asian elephants (Elephas maximus) in Lampung Province, Sumatra, Indonesia. Biol Conserv 124 (1): 35-48. DOI: 10.1016/j.biocon.2005.01.004.

Mingueza LC. 2018. Presence and habitat use of the endangered Borneo elephant (Elephas maximus borneensis) in the INIKEA Rehabilitation Project site (Sabah, Malaysia)-A pilot study. Department of Wildlife, Fish and Environmental Studies, Swedish University of Agricultural Sciences, Uppsala, Sweden.

Mongabay. 2012. Habitat Gajah Borneo Terdesak Alih Fungsi Lahan. https://www.mongabay.co.id/2012/04/18/habitat-gajah-borneoterdesak-alih-fungsi-lahan. [Indonesian]

Othman NB. 2017. Behaviour and Spatial Ecology of the Bornean Elephant (Elephas maximus borneensis) in Lower Kinabatangan, Sabah, Malaysia Borneo. Cardiff University, UK.

Polansky L, Douglas-Hamilton I, Wittemyer G. 2013. Using diel movement behavior to infer foraging strategies related to ecological and social factors in elephants. Movement Ecol 1: 13.

Reilly J. 2002. Growth in the Sumatran elephant (Elephas maximus sumatranus) and age estimation based on dung diameter. J Zool 258 (2): 205-213. DOI: 10.1017/S0952836902001322.

Richard B. 2018. Protecting the elephant transboundary landscape between Sabah dan North Kalimantan. www.panda.org.

Sharma R, Goossens B, Heller R, Rasteiro R, Othman N, Bruford MW, Chikhi L. 2018. Genetic analyses favour an ancient and natural origin of elephants on Borneo. Science Report 8: 880. DOI: 10.1038/s41598-017-17042-5

Sitompul AF. 2011. Ecology and Conservation of Sumatran Elephants (Elephas maximus sumatranus) in Sumatra, Indonesia. [Dissertation]. University of Massachusetts, Amherst, MS.

Sitompul AF, Griffin CR, Rayl ND, Fuller TK. 2013. Spatial and temporal use of an Asian elephant in Sumatra. Animals 3: 670-679.

Sukmantoro W. 2002. Studi Laju Defekasi untuk Estimasi Populasi Gajah Sumatera (Elephas maximus sumatranus Temminck, 1847) di Taman Nasional Way Kambas, Lampung Timur. [Thesis]. InstitutTeknologi Bandung, Bandung. [Indonesian]

Sukmantoro W, Suyitno A, Pramatana F. 2018. Populasi dan Distribusi Gajah Kalimantan di Tulin Onsoi, Kalimantan Utara. Project document of WWF Indonesia-Gajah Kalimantan, Jakarta. [Indonesian]

Sukmantoro YW, Alikodra HS, Kartono AP, Efransjah. 2019. Distribution and habitat preferences of Sumatran elephant (Elephas maximus sumatranus) in Riau, Indonesia. Biodiversitas 20 (1): 226-235. DOI: 10.13057/biodiv/d200126.

Tyson MJ, Hedges S, Sitompul AF. 2002. Elephant defecation rate study, Way Kambas National Park 2000/2001: Final report to WWF, WCS and PHKA. Wildlife Conservation Society-Indonesia Program, Bogor, Indonesia.

Winarno. 2013. Sepuluh gajah di Sabah Malaysia mati akibat racun tikus. www.merdeka.com/peristiwa. [Indonesian]

Wulffraat S. 2006. The elephant of East Kalimantan. Preliminary report, WWF Indonesia, Jakarta.

Wulffraat S, Greenwood C, Faisal KF, Sucipto D, Chan H, Beukeboom H, Soulisa N, Kinasih A. 2017. The Environmental Status of Borneo 2016 Report. Heart of Borneo Programme, Jakarta, Indonesia. 